УДК 35.086(477)

\author{
Н. С. Панова
}

\title{
ДИСЦИПЛІНАРНА ВІДПОВІДАЛЬНІСТЬ ДЕРЖАВНОГО СЛУЖБОВЦЯ ЯК ІНСТИТУТ АДМІНІСТРАТИВНОГО ПРАВА
}

В умовах розвитку й адміністративної реформи у сфері державного управління України для реалізації громадянами своїх прав і виконання ними своїх обов'язків, а також для ефективного державного управління важливе значення має дисциплінарна відповідальність державних службовців. Підвищення ефективності роботи державних службовців тісно пов'язується з розумінням того, що кожний проступок, вчинений державним службовцем під час своєї професійної діяльності, має викликати відповідне реагування з боку компетентних осіб. Водночас державний службовець повинен бути захищеним від дій, вчинків чи рішень керівників [1], що суперечать закону, а дисциплінарну відповідальність він може нести винятково у зв'язку з вчиненням дисциплінарного проступку та в чітко визначеному чинним законодавством порядку.

Повне й усебічне дослідження питань дисциплінарної відповідальності державних службовців $є$ неможливим без визначення та характеристики самого поняття, а також його галузевої приналежності. Аналізуючи дисциплінарну відповідальність державного службовця, варто звернути увагу на те, що на законодавчому рівні немає визначення поняття «дисциплінарна відповідальність». Його не містить ні чинний Закон України «Про державну службу» (1993р.) у частині, що регулює дисциплінарну відповідальність державного службовця, ні Кодекс законів про працю України (далі - КЗпП України) як основний уніфікований акт, що визначає підстави й порядок притягнення до дисциплінарної відповідальності як виду юридичної відповідальності.

Новий Закон України «Про державну» службу» [2], незважаючи на спробу вдосконалити чинні законодавчі норми у сфері дисциплінарної відповідальності державного службовця, також не дає відповіді на це питання. У ньому наводиться лише окрема ремарка щодо того, що дисциплінарна відповідальність полягає в накладенні на державного службовця дисциплінарних стягнень за вчинення дисциплінарних проступків. Однак 
розглядати це трактування як визначення поняття «дисциплінарна відповідальність державного службовця» неможливо, оскільки в ньому йдеться насамперед про ототожнення понять «дисциплінарна відповідальність» і «дисциплінарне провадження».

Якщо звернутись до наукових розвідок, то варто зазначити, що в літературі з трудового права радянського періоду поняття «дисциплінарна відповідальність» зазвичай розглядалось як складова більш загальної проблеми - дисципліни праці. Дисциплінарна відповідальність державних службовців окремо не виділялась, застосовуючись на загальних підставах. Дослідженням проблеми визначення поняття й особливостей дисциплінарної відповідальності державних службовців займався, зокрема, М.Г. Александров, який як ознаку єдиного триваючого трудового правовідношення виокремив його авторитарний характер, що виявлявся в дисципліні праці. До обов'язків працівника вчений відносив виконання роботи та підкорення правилам внутрішнього трудового розпорядку. Відповідно, роботодавцю кореспондувався обов'язок вимагати їі виконання й дотримання трудового розпорядку. Авторитарний характер трудового правовідношення передбачав можливість застосування дисциплінарних заходів щодо працівника [3, с. 39].

Варто зазначити, що правова природа дисциплінарної відповідальності інколи трактувалась досить спрощено. Так, М.А. Тимонов та багато інших науковців відносили дисциплінарний вплив до різновиду державного примусу, оскільки він здійснювався керівництвом державних підприємств фактично від імені держави [5, с. 102]. Окремі автори дотримувались договірної теорії, визначаючи дисциплінарну відповідальність у загальнотеоретичному розумінні як обов'язок працівника відповісти перед роботодавцем за вчинене правопорушення та зазнати заходів впливу, які передбачені в дисциплінарних санкціях трудового права [4, с. 40].

Зрозумілим є те, що дисциплінарна відповідальність - це міра впливу, яка застосовується за порушення трудової дисципліни. Перш ніж визначати дисциплінарну відповідальність державного службовця, необхідно зупинитись на з'ясуванні поняття «дисциплінарна відповідальність». Так, автори підручника «Загальнотеоретична юриспруденція» визначають, що дисциплінарна відповідальність застосовується за порушення дисципліни (трудової, навчальної, службової, військової). Характерною особливістю дисциплінарної відповідальності є іï застосування в порядку службового підпорядкування особи, яка вчинила дисциплінарний проступок [6, с. 304].

Дисциплінарна відповідальність була предметом дослідження багатьох учених у галузі трудового права, і кожен із них наводив їі поняття. Систематизуючи думки науковців, можна стверджувати, що А.А. Абрамова [7, с. 134] та Г.І. Угрюмова [8, с. 79] визначали дисциплінарну відповідальність як окремий вид юридичної відповідальності. А.С. Барабаш [9, с. 194], Д.М. Бахpax [10, с. 41], В.І. Никитинський [11, с. 5], Л.О. Сироватська [12, с. 135] та В.В. Форманюк [13, с. 195] розуміють дисциплінарну відповідальність як міру впливу, що застосовується до особи за вчинення дисциплінарного 
проступку. У свою чергу Н.Б. Болотіна [14], К.В. Коваленко [15, с. 235], Г.Г. Петришина-Дюг [4, с. 41], Г.І. Чанишева [14] визначають дисциплінарну відповідальність як обов'язок працівника зазнати несприятливих наслідків за скоєння дисциплінарного порушення.

Аналізуючи наведені думки дослідників, варто зауважити, що визначені поняття дисциплінарної відповідальності розуміються вченими в загальному вигляді та не називають особливості відповідальності окремих категорій працівників з огляду на специфіку їх роботи. Так, залежно від джерел правового регулювання виокремлюють два види дисциплінарної відповідальності: загальну та спеціальну. Такий поділ обумовлюється трьома підставами: по-перше, включенням особи в той чи інший тип колективу; по-друге, належністю громадянина до організації певного виду (наприклад, особливо регулюється відповідальність працівників підприємств та установ систем різних транспортних міністерств, працівників прокуратури, суддів та інших); по-третє, характером функцій, виконуваних особою в цій організації. Має своєрідну регламентацію відповідальність тих працівників, діяльність яких становить основний зміст конкретної організації: суддів, прокурорів, слідчих прокурорів та інших (на відміну від осіб, які виконують у тій же організації допоміжні функціі). Наведені чинники обумовлюють специфіку підстав відповідальності, переліків стягнень, ієрархії дисциплінарної влади, процесуальних форм, визначаючи, відповідно, диференціацію дисциплінарної відповідальності $[16 ; 17 ; 18]$.

Загальна дисциплінарна відповідальність регулюється КЗпП України й правилами внутрішнього трудового розпорядку та поширюється на всіх працівників, окрім працівників, для яких встановлено спеціальну дисциплінарну відповідальність. Загальну дисциплінарну відповідальність встановлено для всіх робітників і службовців. ІІї правила, що визначають види стягнень, порядок їх застосування й зняття, певною мірою віддзеркалюються також у спеціальній дисциплінарній відповідальності, проте остання має багато особливостей, є винятком. Саме тому в усіх випадках, коли не може бути застосовано спеціальну дисциплінарну відповідальність, діє загальна.

Спеціальна дисциплінарна відповідальність передбачається лише для конкретно визначених категорій працівників на підставі статутів і положень про дисципліну та спеціальних нормативних актів. Вона характеризується спеціальним суб'єктом дисциплінарного проступку, спеціальними трудовими функціями, особливим характером дисциплінарного проступку, особливо тяжкими наслідками, які можуть настати в результаті невиконання чи неналежного виконання трудових обов'язків, спеціальними видами дисциплінарних стягнень, особливим порядком накладення й оскарження дисциплінарного стягнення. Спеціальним суб'єктом є працівник, який несе дисциплінарну відповідальність за спеціальними нормативно-правовими актами (законами, статутами, положеннями). Спеціальна дисциплінарна відповідальність працівників відрізняється від загальної дисциплінарної відповідальності більш широким змістом дисциплінарного проступку та 
більш суворими санкціями. Так, для певних категорій працівників вимоги морального змісту включено до їхніх трудових обов'язків [15, с. 234]. Це стосується, наприклад, державних службовців (ст. 5 Закону України «Про державну службу»). 3 прийняттям нового Закону України «Про державну службу» зазначені вимоги морального змісту отримали назву професійної етики державного службовця, а порушення вимог такої етики було віднесено до дисциплінарних проступків. Відповідно, недотримання вказаних норм $€$ підставою для притягнення такого працівника до дисциплінарної відповідальності. Окрім того, ще одна особливість спеціальної дисциплінарної відповідальності проявляється в тому, що на працівників, які несуть відповідальність за статутами, положеннями та іншими актами законодавства про дисципліну, дисциплінарні стягнення можуть накладатись не лише органом, який приймає (призначає) на роботу (посаду), а й спеціальними органами (зокрема, щодо суддів ними є Вища кваліфікаційна комісія суддів України, Вища рада юстиції) [2, ст. 85].

Найхарактернішими рисами спеціальної дисциплінарної відповідальності є такі: а) обмежена сфера й коло суб’єктів ії застосування; б) специфічні заходи дисциплінарного впливу (зазвичай більш жорсткі стягнення); в) визначене коло суб'єктів, які можуть іï застосовувати; г) особливий порядок накладення та оскарження дисциплінарних стягнень; г) наявність спеціальних нормативних актів. Таким чином, спеціальна дисциплінарна відповідальність - це окремий вид дисциплінарної відповідальності чітко визначених суб'єктів, які за вчинений дисциплінарний проступок у межах спеціальних нормативних актів можуть залучатись до більш жорстких заходів дисциплінарного впливу з особливим порядком накладення й оскарження дисциплінарних стягнень [19, с. 102].

У теорії трудового права також можна виокремити спеціальну дисциплінарну відповідальність згідно зі статутами та положеннями про дисципліну (працівників залізничного транспорту, зв'язку). Що стосується відповідальності окремих категорій працівників, то ії особливість пов'язується 3 існуванням окремих підзаконних актів, які регламентують дисциплінарну відповідальність конкретних працівників [20]. У цьому разі не виникає жодних спірних моментів, оскільки зрозуміло, що дисциплінарна відповідальність таких працівників регулюється нормами трудового права.

Питанням визначення поняття «дисциплінарна відповідальність» займалися також учені-адміністративісти. Науковці прагнули виокремити особливості відповідальності державних службовців та розглядали дисциплінарну відповідальність як інститут адміністративного права. Вивчаючи підходи учених-адміністративістів щодо визначення дисциплінарної відповідальності державних службовців, можна класифікувати їх залежно від підстав визначення. Так, І.Л. Бородін [21, с. 94], як і науковці в галузі трудового права, розглядає дисциплінарну відповідальність як вид юридичної відповідальності. Як правовий інститут дисциплінарну відповідальність аналізують Л.Р. Біла-Тіунова [22, с. 277-278], Н.М. Вапнярчук [19, с. 101; 23, с. 9], С.В. Ківалов [22, с. 277-278] та О.В. Клімкіна [24]. У свою чергу 
В.В. Зуй [25, с. 197], О.Ю. Оболенський [26, с. 267-268] та Д.М. Овсянко $[27$, с. 173$]$ визначають дисциплінарну відповідальність державних службовців через застосування заходів впливу за винні порушення правил державної служби.

Дисертація I.О. Картузової стала теоретичною базою для написання низки наукових розвідок із цього питання. Автор визначає підстави застосування такої відповідальності, стадії дисциплінарного провадження, що може застосовуватись до державних службовців [28]. I.О. Картузова розуміє дисциплінарну відповідальність державних службовців як зазнавання державним службовцем позбавлень та обмежень особистого чи майнового характеру за здійснення дисциплінарного проступку або іншого порушення, за яке, згідно із законом, передбачається застосування заходів дисциплінарної відповідальності уповноваженими на те суб'єктами [29, с. 9]. У роботі вчений досить влучно зазначила, що доцільним і необхідним у сучасний період $€$ розмежування дисциплінарної відповідальності в трудовому праві та дисциплінарної відповідальності в адміністративному праві. Дисциплінарна відповідальність державних службовців через специфіку державно-управлінської діяльності, яку вони здійснюють, підлягає регулюванню нормами адміністративного права [29, с. 9-10].

Дійсно, аналізуючи законодавчі норми, варто зробити висновок про те, що для певних видів державних службовців дисциплінарна відповідальність передбачається не лише Законом України «Про державну службу» та КЗпП України, а й статутами та положеннями. Проте серед усіх осіб, які уповноважені на виконання функцій держави, можна виокремити різні статуси: і політичних діячів, і державних службовців. Оскільки дисциплінарна відповідальність тлумачиться з огляду на поділ на загальну та спеціальну, то більш правильно класифікувати дисциплінарну відповідальність державних службовців на відповідальність загального характеру (передбачену Законом України «Про державну службу» й КЗпП України) та відповідальність особливого характеру - статутну (окрім зазначених нормативних актів, регламентується також статутами й положеннями).

Дисциплінарна відповідальність як самостійний вид юридичної відповідальності є особливим елементом у структурі правової системи, важливим фактором, що забезпечує правомірну поведінку державного службовця під час виконання ним своїх повноважень. Вона характеризується наявністю власної підстави (дисциплінарного проступку), особливих санкцій (дисциплінарних стягнень), спеціального суб'єкта дисциплінарного проступку та суб’єкта дисциплінарної влади, який уповноважений застосувати дисциплінарне стягнення у встановленому порядку [30, с. 85-86].

Таким чином, наведені поняття й особливості дисциплінарної відповідальності дають змогу сформулювати власну дефініцію поняття дисциплінарної відповідальності державних службовців та визначити низку іiі принципових особливостей. Так, дисциплінарна відповідальність державних службовців - це застосування до державних службовців негативних заходів вПливу особистого чи майнового характеру за невиконання або 
неналежне виконання покладених на них обов'язків або вчинення інших дисциплінарних проступків, що здійснюється уповноваженим суб'єктом згідно із законодавчими нормами.

Незважаючи на тотожність багатьох понять та інститутів, дисциплінарна відповідальність у межах трудового й адміністративного права має серйозні відмінності, наявність яких дає підстави для диференціації дисциплінарної відповідальності за суб'єктним складом та виділення двох окремих видів дисциплінарної відповідальності: загальної (трудової) і спеціальної (адміністративної) [31, с. 91]. 3 огляду на зазначене дисциплінарна відповідальність державного службовця відрізняється від загальної трудової дисциплінарної відповідальності насамперед такими ознаками:

1) має особливий суб’єкт відповідальності (спеціальний). Суб’єктом дисциплінарної трудової відповідальності є працівник - головний суб'єкт трудового права, чиї відносини з роботодавцем регулюються нормами трудового законодавства. Суб'єктом дисциплінарної адміністративної відповідальності є головний індивідуальний суб'єкт адміністративного права - державний службовець. Ю.М. Старілов влучно зазначає: «Головна відмінність між державним службовцем і працівником полягає в тому, що особи, які перебувають на державній службі, на відміну від осіб, які перебувають у звичайних трудових відносинах, мають особливий публічно-правовий статус» [32, с. 17]. Відповідно до Закону України «Про державну службу» державний службовець - це громадянин України, який обіймає посаду державної служби в державному органі, органі влади Автономної Республіки Крим або їх апараті, отримує заробітну плату за рахунок коштів державного бюджету, крім випадків, визначених законом, та здійснює встановлені для цієї посади відповідні повноваження, безпосередньо пов'язані з реалізацією завдань і виконанням функцій державного органу чи органу влади Автономної Республіки Крим. Отже, основні ознаки державного службовця є такими: а) громадянин України; б) зайняття посади державної служби; в) діяльність у державному органі, органі влади Автономної Республіки Крим або ї апараті; г) заробітна плата за рахунок коштів державного бюджету, крім випадків, визначених законом; г) здійснення відповідних повноважень, визначених законом. При цьому важливо зазначити, що до державних службовців не належать особи, які проходять стажування в державних органах, оскільки вони не займають посад у цих органах, а лише претендують на них. Важливою ознакою державного службовця є також місце здійснення його професійної діяльності - державний орган, орган влади Автономної Республіки Крим або ix апарат. Державний орган - це особливий вид організації людей, який характеризується такими ознаками: а) є організованим колективом; б) є автономною частиною державного апарату; в) здійснює державні функції, реалізує публічний інтерес; г) діє від імені держави та водночас від свого імені; г) володіє власною компетенцією; д) несе відповідальність перед державою за свою діяльність; е) засновується державою; є) його становище, структура й діяльність регламентуються правом; 
2) має особливі джерела правового регулювання - адміністративні акти. 3 одного боку, питання дисциплінарної відповідальності є обов'язковим елементом системи трудового права, регламентованим КЗпП України [33, ст. 159-162], та виконує важливі функції в процесі реалізації конституційного права громадян на працю [1]. 3 іншого боку, будучи інститутом адміністративного права, дисциплінарна відповідальність державного службовця має досить об'ємну адміністративно-правову регламентацію, забезпечуючи конституційне право громадян на участь в управлінні державою. Відповідно, основним джерелом правового регулювання дисциплінарної відповідальності державних службовців $€$ насамперед норма адміністративного права, а саме Закон України «Про державну службу». Проте, на жаль, сьогодні питання дисциплінарної відповідальності державних службовців є «розсіяними» в різних законодавчих актах і несистематизованими;

3) має особливості фактичних підстав застосування відповідальності. Дисциплінарна відповідальність застосовується в разі вчинення дисциплінарного проступку. Підстави застосування дисциплінарної адміністративної відповідальності визначаються відповідними нормами права;

4) має види форм впливу, які для державних службовців визначаються в Законі України «Про державну службу» та застосовуються паралельно 3 нормами КЗпП України. Дисциплінарна відповідальність, згідно з нормами трудового права, застосовується у формі дисциплінарних стягнень. Що ж стосується відповідальності державних службовців, то, крім дисциплінарних стягнень, до них можуть застосовуватись також заходи дисциплінарного впливу (ст. 14 Закону України «Про державну службу»), особливі види дисциплінарних стягнень, закріплені в ст. 53 Закону України «Про державну службу» (2011 р.) [2];

5) має порядок накладення стягнень. У цьому разі, незважаючи на певну універсальність порядку притягнення державного службовця до дисциплінарної відповідальності порівняно із загальним порядком, що встановлюється трудовим законодавством, є низка особливостей цієї процедури. Так, особливістю $є$ те, що перед накладенням стягнення в низці випадків законодавство вимагає проведення службового розслідування;

6) має особливу сферу застосування дисциплінарної відповідальності - державне управління. Галузева приналежність дисциплінарної відповідальності державних службовців, окрім правової моделі, обумовлюється «сутнісною» природою державно-службових відносин, їх структурою та змістом. Аналізуючи зміст службових і трудових відносин, С.Б. Поляков визначив, що в трудових правовідносинах роботодавцем є підприємство, метою якого $є$ самозабезпечення, саморозвиток шляхом отримання прибутку від результатів своєї діяльності [34, с. 23-24]. Правовідносини, що виникають у такому випадку, як правило, передбачають рівність учасників. Зміст таких правовідносин включає взаємні права й обов'язки роботодавця та працівника. У службових правовідносинах наймачем виступає держава в особі органів та установ, діяльність яких спрямовується не на задоволен- 
ня власних цілей, а на реалізацію функцій держави. У свою чергу основа діяльності державних службовців полягає в реалізації й забезпеченні прав і свобод людини та громадянина.

Під час характеристики державно-службових відносин варто зазначити, що це - правовідносини, для яких застосовується винятково метод нормативного регулювання, тобто застосування законів і підзаконних нормативно-правових актів. Натомість метод договірного регулювання, який $є$ основним у трудовому праві, не може застосовуватись щодо державно-службових відносин, оскільки ці відносини виникають під час реалізації публічного, а не приватного інтересу, тобто у сфері функціонування державних органів і їхніх посадових осіб, стосовно яких діє принцип «дозволено лише те, що передбачено законодавством». Щодо методу договірного регулювання державно-службових відносин варто зауважити, що його частка є настільки незначною, що не може суттєво вплинути на їх природу в цілому.

Також наголосимо, що державно-службові відносини - це «владовідносини», тобто їх учасники є юридично нерівними, оскільки однією зі сторін завжди є державний орган або посадова особа - «суб'єкт призначення», якого наділено певними державно-владними повноваженнями щодо іншої сторони, яка у свою чергу підпорядковується першій та зобов'язана виконувати всі їі приписи й розпорядження, за винятком випадків, передбачених чинним законодавством. Таким чином, державний службовець завжди перебуває в службовій підлеглості щодо суб'єкта призначення, що є однією з ознак інституту державної служби як ієрархічної системи.

Важливо те, що державно-службові відносини - це статусні службові відносини, оскільки вони здебільшого визначають правовий статус (правове становище) державних службовців. 3 огляду на те, що державні службовці є однією зі сторін цих відносин, чинним законодавством вони наділяються певними правами, обов'язками та повноваженнями, щодо них передбачаються обмеження й заборони, гарантії та умови здійснення державної служби, правовий захист і юридична відповідальність, тобто визначається їхній правовий статус.

Важливо зазначити, що більшість державно-службових відносин регулюються нормами публічних галузей права: конституційного, адміністративного, фінансового, кримінального. Частка відносин, що регламентуються КЗпП України (робочий час, службові відрядження, загальні підстави припинення державної служби), є незначною та суттєво не впливає на сутність інституту державної служби як публічної інституції. При цьому варто вказати, що відповідно до подальшого розвитку інституту державної служби, удосконалення законодавства про державну службу, його адаптації до стандартів Європейського Союзу відбувається поступове й цілеспрямоване звуження кола суспільних відносин, на які поширюється дія норм трудового права на користь норм адміністративного права.

Зміст державно-службових відносин характеризується правами й обов'язками сторін цих відносин, яким притаманний державно-владний характер із таких причин: 
1) ці відносини виникають у сфері функціонування державних органів та їх апарату;

2) пов'язані з реалізацією державно-владних повноважень як суб'єктом призначення, так і державним службовцем, який виступає від імені держави за дорученням держави з використанням державно-владних повноважень, делегованих йому державою;

3) ці відносини спрямовуються на забезпечення реалізації або захисту публічного інтересу (прав, свобод і законних інтересів фізичних та юридичних осіб);

4) гарантуються державою, у тому числі через державний примус;

5) перелік прав та обов'язків сторін визначається чинним законодавством.

Державно-службові відносини являють собою відносини, що виникають із приводу забезпечення виконання завдань і функцій держави. Ця особливість логічно постає з поняття державної служби, у якому зазначається, що це «професійна діяльність <..> з підготовки пропозицій щодо формування державної політики, забезпечення іiі реалізації та надання адміністративних послуг». Тобто державний службовець, здійснюючи цю діяльність, вступає у відповідні правовідносини (державно-службові) з метою реалізації не своїх, а публічних інтересів, не власних, а державно-владних повноважень, не від свого імені, а від імені держави. Лише держава безпосередньо чи опосередковано, через чинне законодавство, визначає статус державного службовця: його завдання й функції, права та обов'язки, повноваження й обмеження. Тобто без такого визначення фізична особа не володіла б статусом державного службовця. 3 іншого боку, саме державний службовець забезпечує реалізацію завдань і функцій держави, оскільки це є основним його призначенням, без нього реалізація завдань і функцій держави просто була б неможливою.

Особливістю державно-службових відносин $є$ те, що вони характеризуються наявністю обов'язкових сторін, якими є, з одного боку, суб'єкт призначення - державний орган або його апарат (посадова особа), а з іншого державний службовець. Відсутність хоча б однієї з наведених сторін свідчить про відсутність державно-службових відносин. Винятком із цього положення $€$ державно-службові відносини, що виникають під час набуття особою статусу державного службовця, коли замість державного службовця стороною цих відносин є громадянин, який претендує на посаду державного службовця, тобто його можна розглядати як кандидата на державну службу.

Для державно-службових відносин $€$ характерним також те, що вони можуть виникати, змінюватись і припинятись за ініціативи однієї зі сторін: або суб'єкта призначення, або державного службовця. Тобто вони можуть реалізуватись таким чином: а) державний орган або його апарат (посадова особа) - державний службовець; б) державний службовець - державний орган або його апарат (посадова особа). При цьому для виникнення подібних правовідносин згода іншої сторони є необхідною лише в тому разі, якщо це передбачено чинним законодавством. 
Державно-службові відносини - це відносини довіри й відданості державного службовця. Ця ознака логічно постає з двоєдиної сутності державного службовця, який, з одного боку, перебуває на службі в держави, тобто є слугою держави (обіймає державну посаду, наділяється державними повноваженнями, виступає від імені держави, захищається державою, отримує зарплату від держави тощо), є підвідомчим відповідним владним суб'єктам, а з іншого - здійснює свою діяльність заради суспільства (народу України), якому й присягав. Отже, державний службовець у випадках, передбачених чинним законодавством, має право не виконувати окремі розпорядження безпосередніх керівників, що мають характер незаконних і суперечать інтересам народу. Водночас це положення не поширюється на випадок протиріч між інтересами держави та інтересами державного службовця, оскільки для державної служби важливим є принцип пріоритету державних інтересів.

Державно-службові відносини є переважно субординаційними, оскільки виникають у сфері державної служби, яка за свою сутністю є ієрархічною системою (ієрархія державних органів, ієрархія державних посад), тобто системою, якій притаманні насамперед влада й підпорядкування.

3 огляду на низку особливостей дисциплінарної відповідальності державних службовців порівняно із загальною дисциплінарною відповідальністю можна зробити висновок, що дисциплінарна відповідальність державних службовців $є$ інститутом саме адміністративного права. Проблемою в цьому разі є відсутність нормативного констатування такої відповідальності.

Вважаємо за доцільне чітко закріпити в національному законодавстві галузеву приналежність інституту дисциплінарної відповідальності державних службовців, а саме у відповідному систематизованому акті у сфері державної служби.

\section{Література}

1. Корнута Л.М. Перспективи розвитку функцій державного управління економікою України / Л.М. Корнута // Актуальні проблеми держави і права : зб. наук. праць / за ред. С.В. Ківалова. - О. : Юридична література, 2011. - Вип. 60. - С. 331-337.

2. Про державну службу : Закон України від 17 листопада 2011 р. № 4050-VI [Електронний pecypc]. - Режим доступу : http://zakon3.rada.gov.ua/laws/show / 4050-17.

3. Александров Н.Г. Советское трудовое право / Н.Г. Александров, Г.К. Москаленко. М. : Юриздат, 1950. - 358 с.

4. Петришина-Дюг Г.Г. Дисциплінарна відповідальність у трудовому праві: поняття та принципи / Г.Г. Петришина-Дюг / / Науковий вісник Чернівецького університету. Серія «Правознавство». - Чернівці : Рута, 2008. - Вип. 461. - С. 39-42.

5. Тимонов Н.А. Трудовой распорядок на предприятии / Н.А. Тимонов - М. : Велби, 1977. - 166 с.

6. Общетеоретическая юриспруденция : [учебник] / [Ю.Н. Оборотов, В.В. Завальнюк, В.В. Дудченко, Н.Н. Крестовская] ; под ред. Ю.Н. Оборотова. - О. : Феникс, 2011. - 436 с.

7. Абрамова А.А. Дисциплина труда в СССР / А.А. Абрамова. - М. : Юридическая литература, 1969. - 176 с.

8. Угрюмова Г.І. Загальна характеристика дисциплінарної відповідальності і дисциплінарного проступку за українським трудовим правом / Г.І. Угрюмова / / Право України. - 2005. - № 5. C. $78-81$.

9. Барабаш А.С. Общая теория права / А.С. Барабаш. - К. : Наукова думка, 2002. - 246 с.

10. Бахрах Д.Н. Особенности дисциплинарной ответственности как вида юридической ответственности / Д.Н. Бахрах // Современное право. - 2008. - № 10. - С. 40-41. 
11. Никитинский В.И. Ответственность рабочих и служащих за нарушение трудовой дисциплины по советскому трудовому праву : автореф. дисс. ... канд. юрид. наук / В.И. Никитинский ; Всесоюзный ин-т юрид. наук МЮ СССР. - М., 1955. - 14 с.

12. Сыроватская Л.А. Трудовое право : [учебник для вузов] / Л.А. Сыроватская. - М. : Высшая школа, 1995. - 254 с.

13. Форманюк В.В. Дисциплінарна відповідальність: теоретичний аналіз / В.В. Форманюк / / Актуальні проблеми політики. - 2010. - Вип. 40. - С. 191-195.

14. Болотіна Н.Б. Трудове право України / Н.Б. Болотіна, Г.І. Чанишева [Електронний ресурс]. - Режим доступу : http://pravoznavec.com.ua/books/letter/15/\%C1/1197\#chapter.

15. Коваленко К.В. Загальна та спеціальна дисциплінарна відповідальність / К.В. Коваленко / / Форум права. - 2008. - № 2. - С. 231-236. - [Електронний ресурс]. - Режим доступу : http: / / www.nbuv.gov.ua/journals / FP / 2008-2/08kkvsdv.pdf.

16. Скобелкин В.Н. Дисциплинарная и материальная ответственность рабочих и служащих / В.Н. Скобелкин. - Воронеж : Центр.-Чернозем. кн. изд-во, 1990. - 223 с

17. Адушкин Ю.С. Дисциплинарное производство в СССР / Ю.С. Адушкин / под ред. B.M. Манохина. - Саратов : Изд-во Саратовского ун-та, 1986. - 128 с.

18. Про судоустрій і статус суддів : Закон України від 7 липня 2010 р. № 2453-VI [Електронний ресурс]. - Режим доступу : http:/ / zakon0.rada.gov.ua/laws/show/2453-17.

19. Вапнярчук Н.M. Актуальні питання дисциплінарної відповідальності державних службовців в Україні / Н.М. Вапнярчук / / Форум права. - 2009. - № 3. - С. 100-104. - [Електронний ресурс]. - Режим доступу : http:/ / www.nbuv.gov.ua/e-journals/FP/2009-3/09vnmcvu. pdf.

20. Про Положення про дисципліну працівників залізничного транспорту : Постанова Кабінету Міністрів України від 26 січня 1993 р. № 55 [Електронний ресурс]. - Режим доступу : http: / / zakon5.rada.gov.ua/laws/ show/55-93-п.

21. Бородін І.Л. Дисциплінарна відповідальність та дисциплінарне провадження / І.Л. Бородін / / Право України. - 2006. - № 12. - С. 93-97.

22. Ківалов С.В. Публічна служба в Україні : [підручник] / С.В. Ківалов, Л.Р. Біла-Тіунова. - О. : Фенікс, 2009. - 688 с.

23. Вапнярчук Н.М. Правове регулювання дисциплінарної відповідальності державних службовців в Україні : автореф. дис. ... канд. юрид. наук : спец. 12.00.05 «Трудове право; право соціального забезпечення» / Н.М. Вапнярчук ; Східноукраїнський нац. ун-т ім. В. Даля. Луганськ, 2010. - 20 с.

24. Климкина Е.В. Административно-правовое регулирование дисциплинарной ответственности государственного гражданского служащего России : дисс. ... канд. юрид. наук : спец. 12.00.14 «Административное право; финансовое право; информационное право» / Е.В. Климкина ; Московский ун-т МВД России. - М., 2006. - 204 с.

25. Адміністративне право України : [підручник] / [Ю.П. Битяк, В.М. Гаращук, О.В. Дяченко, В.В. Зуй та ін.] ; за ред. Ю.П. Битяка. - К. : Юрінком Інтер, 2006. - 544 с.

26. Оболенський О.Ю. Державна служба : [підручник] / О.Ю. Оболенський. - К. : КНЕУ, 2006. -472 c.

27. Овсянко Д.М. Государственная служба Российской Федерации : [учеб. пособие для студ. юрид. фак-тов и ин-тов] / Д.М. Овсянко ; отв. ред. Г.А. Туманов. - М. : Юристъ, 1996. - 208 с.

28. Картузова I.О. Дисциплінарна відповідальність державних службовців : дис. ... канд. юрид. наук : спец. 12.00.07 «Теорія управління; адміністративне право і процес; фінансове право; банківське право» / I.О. Картузова ; Одеська держ. юрид. академія. - О., 1999. - 196 с.

29. Картузова I.О. Дисциплінарна відповідальність державних службовців : автореф. дис. ... канд. юрид. наук : спец. 12.00 .07 «Теорія управління; адміністративне право і процес; фінансове право; банківське право» / I.О. Картузова ; Одеська держ. юрид. академія. - О., 1999. - 18 с.

30. Корнута Л.М. Дисциплінарна відповідальність державного службовця в Україні: теоретичний та практичний аспекти / Л.М. Корнута / / Актуальні проблеми держави і права : зб. наук. праць / за ред. С.В. Ківалова. - О. : Юридична література, 2011. - Вип. 62. - С. 84-90.

31. Добробаба М.Б. Отраслевая принадлежность дисциплинарной ответственности государственных служащих Российской Федерации / М.Б. Добробаба / / Современное право. 2008. - № 4. - C. 90-94. 
32. Старилов Ю.Н. К вопросу о публично-правовом характере института государственной службы / Ю.Н. Старилов // Правоведение. - 1997. - № 1. - С. 17-33.

33. Кодекс законів про працю України від 10 грудня 1971 р. № 322-VIII [Електронний ресурс]. - Режим доступу : http://zakon2.rada.gov.ua/laws/show/322-08.

34. Поляков С.Б. Регулирование служебных и трудовых правоотношений / С.Б. Поляков / / Российская юстиция. - 1998. - № 12. - С. 23-25.

\section{Ано т а ці я}

Панова Н. С. Дисциплінарна відповідальність державного службовця як інститут адміністративного права. - Стаття.

Статтю присвячено визначенню галузевої приналежності дисциплінарної відповідальності державного службовця. Особливу увагу приділено аналізу наукових напрацювань із питань дисциплінарної відповідальності державного службовця, стану ії правового регулювання, співвідношенню дисциплінарної відповідальності за трудовим та адміністративним правом.

Ключові слова: державний службовець, дисциплінарна відповідальність, державнослужбові відносини, адміністративний акт, спеціальний суб'єкт адміністративного проступку.

\section{Аннот а ция}

Панова H. С. Дисциплинарная ответственность государственного служащего как институт административного права. - Статья.

Статья посвящена определению отраслевой принадлежности дисциплинарной ответственности государственного служащего. Особенное внимание уделяется анализу научных разработок по вопросам дисциплинарной ответственности государственного служащего, состоянию ее правового регулирования, соотношению дисциплинарной ответственности по трудовому и административному праву.

Ключевые слова: государственный служащий, дисциплинарная ответственность, государственно-служебные отношения, административный акт, специальный субъект административного проступка.

\section{S u m m a r y}

Panova N. S. Disciplinary responsibility of the state servant as the administrative law institute. - Article.

The article is devoted to the definition of the field accessary of the disciplinary responsibility of the state servant. Special attention is devoted to the analyses of the science development concerning disciplinary responsibility of the state servant, the state of its legal regulation, correlation of the disciplinary responsibility in administrative and labor law.

Key words: state servant, disciplinary responsibility, state-official relations, administrative act, special subject of the administrative offence. 